\title{
Temporal Dynamics in Soil Oxygen and Greenhouse Gases in Two Humid Tropical Forests
}

\author{
Daniel Liptzin, ${ }^{1,2 *}$ Whendee L. Silver, ${ }^{1}$ and Matteo Detto ${ }^{1}$
}

\footnotetext{
${ }^{1}$ Department of Environmental Science, Policy, \& Management, University of California at Berkeley, Berkeley, California 94720, USA; ${ }^{2}$ Department of Land, Air \& Water Resources, University of California at Davis, Davis, California 95616, USA
}

\begin{abstract}
Soil redox plays a key role in regulating biogeochemical transformations in terrestrial ecosystems, but the temporal and spatial patterns in redox and associated controls within and across ecosystems are poorly understood. Upland humid tropical forest soils may be particularly prone to fluctuating redox as abundant rainfall limits oxygen $\left(\mathrm{O}_{2}\right)$ diffusion through finely textured soils and high biological activity enhances $\mathrm{O}_{2}$ consumption. We used soil equilibration chambers equipped with automated sensors to determine the temporal variability in soil oxygen concentrations in two humid tropical forests with different climate regimes. We also measured soil trace gases $\left(\mathrm{CO}_{2}, \mathrm{~N}_{2} \mathrm{O}\right.$, and $\left.\mathrm{CH}_{4}\right)$ as indices of redox-sensitive biogeochemistry. On average, the upper elevation cloud forest had significantly lower $\mathrm{O}_{2}$ concentrations $(3.0 \pm 0.8 \%)$ compared to the lower elevation wet tropical forest $(7.9 \pm 1.1 \%)$. Soil $\mathrm{O}_{2}$ was dynamic, especially in
\end{abstract}

the wet tropical forest, where concentrations changed as much as $10 \%$ in a single day. The periodicity in the $\mathrm{O}_{2}$ time series at this site was strongest at 16 day intervals and was associated with the hourly precipitation. Greenhouse gas concentrations differed significantly between sites, but the relationships with soil $\mathrm{O}_{2}$ were consistent: $\mathrm{O}_{2}$ was negatively related to both $\mathrm{CO}_{2}$ and $\mathrm{CH}_{4}$ and positively related to $\mathrm{N}_{2} \mathrm{O}$. These results are among the first to quantify the temporal and spatial scale of variability in soil redox in humid tropical forests, and show that the timing of precipitation plays a strong role in biogeochemical cycling on the scale of hours to weeks.

Key words: soil oxygen; greenhouse gases; tropical forests; soil redox; biogeochemical cycling; wavelet analysis.

\section{INTRODUCTION}

Oxygen $\left(\mathrm{O}_{2}\right)$ is a fundamental driver of biogeochemical cycling on Earth. Oxygen concentrations are intimately tied to carbon (C) fixation and oxidation, and are an important driver of the anti-

Received 9 July 2010; accepted 15 October 2010; published online 7 December 2010

Author Contributions: DL and WLS conceived of or designed study; DL performed research; DL, WLS, MD analyzed data; DL, WLS, MD wrote the paper.

*Corresponding author; e-mail: liptzin@ucdavis.edu phase fluctuations of $\mathrm{O}_{2}$ and carbon dioxide $\left(\mathrm{CO}_{2}\right)$ in the atmosphere at annual time scales (Keeling and Severinghaus 2000). Oxygen, by its control of redox potential, influences a considerable proportion of nutrient cycles as well. Some elements (for example, nitrogen $(\mathrm{N})$, sulfur $(\mathrm{S})$, iron $(\mathrm{Fe})$, manganese $(\mathrm{Mn})$ ) have multiple redox states. Other elements such as phosphorus are only indirectly related to redox state through its interactions with redox-active elements, especially Fe (Baldwin and Mitchell 2000). The contemporary surface of Earth is a highly oxidizing environment. However, reducing conditions exist in 
soils, sediments, and water columns. Key biogeochemical pathways, mediated by microbial processes associated with $\mathrm{C}$ oxidation, occur in these anoxic environments.

The greenhouse gases $\mathrm{CO}_{2}$, nitrous oxide $\left(\mathrm{N}_{2} \mathrm{O}\right)$ and methane $\left(\mathrm{CH}_{4}\right)$ are produced and consumed in soils via redox reactions. Carbon oxidation produces $\mathrm{CO}_{2}$ as a byproduct of aerobic respiration, or as the product of anaerobic respiration or fermentation. For example, Fe and $\mathrm{Mn}$ reduction can be coupled to $\mathrm{C}$ oxidation in the absence of $\mathrm{O}_{2}$, producing $\mathrm{CO}_{2}$ (Lovley 1991; Ponnamperuma 1972). Denitrification represents the major loss pathway of reactive $\mathrm{N}$ from the biosphere to the atmosphere converting nitrate to unreactive dinitrogen gas or nitrous oxide $\left(\mathrm{N}_{2} \mathrm{O}\right)$ under anaerobic conditions (Seitzinger and others 2006). Methanogenesis is also an important redox-sensitive process as either $\mathrm{CO}_{2}$ or simple organic compounds are reduced to methane $\left(\mathrm{CH}_{4}\right)$ under anaerobic conditions.

Most of the research on redox dynamics has been conducted in wetlands, water columns, and aquatic sediments which can experience near constant anoxic conditions for months to years. Upland soils can also experience low redox, but unlike aquatic systems, redox tends to fluctuate in soils, both spatially and temporally (Silver and others 1999; Schuur and Matson 2001). Despite the fact that abundant evidence exists for redox-active biogeochemical cycling in upland soils, the links between $\mathrm{O}_{2}$ concentrations and biogeochemically relevant redox reactions are poorly understood in these environments. Oxygen can be rapidly consumed in some finely textured soils faster that it can be resupplied via diffusion, leading to low redox conditions. Within soil aggregates, $\mathrm{O}_{2}$ concentrations can decrease from oxic to anoxic over a distance of millimeters (Sexstone and others 1985).

Redox dynamics may be particularly important where warm, wet conditions, finely textured soils, and high biological activity increase the likelihood of anoxic events. Warm temperatures stimulate biological activity and decrease the solubility of $\mathrm{O}_{2}$ in water (Weiss 1970). High rainfall typical of the humid tropics leads to periods of high water content (for example, Cleveland and Townsend 2006). Tropical soils are predominantly oxisols and ultisols which tend to be clay-rich with high water-holding capacity (Vitousek and Sanford 1986). This combination may lead to periods when the $\mathrm{O}_{2}$ demand outpaces the supply driving down bulk soil $\mathrm{O}_{2}$ concentrations. Redox dynamics in these soils have been shown to affect the cycling of N, Fe, and P (via Fe reduction and oxidation), as well as microbial community composition and activity (Silver and others 2001, 2005; Chacon and others 2006; Thompson and others 2006; Peretyazhko and Sposito 2005; Pett-Ridge and others 2006; Liptzin and Silver 2009; Dubinsky and others 2010; DeAngelis and others 2010). Tropical forest soils are well documented sources of $\mathrm{CO}_{2}, \mathrm{~N}_{2} \mathrm{O}$, and $\mathrm{CH}_{4}$ (Keller and others 1986; Teh and others 2005; Frankenberg and others 2008; Melillo and others 2001; Vitousek and Matson 1992). However, the temporal scale of redox fluctuations and spatial heterogeneity in the redox environment are not well documented in these ecosystems. Furthermore, the relationships between fluctuations in soil $\mathrm{O}_{2}$ concentrations, a proxy for fluctuating redox, and greenhouse gas concentrations in soils is poorly understood.

The goals of this study were to explore the spatial and temporal patterns in soil $\mathrm{O}_{2}$ concentrations and examine the relationships with precipitation and temperature as climatic drivers. We chose two sites at opposite ends of an elevational climate gradient in Puerto Rico to make, to our knowledge, the first continuous (hourly) $\mathrm{O}_{2}$ measurements in upland soils. We also determined the relationship of $\mathrm{O}_{2}$ with $\mathrm{CO}_{2}, \mathrm{~N}_{2} \mathrm{O}$, and $\mathrm{CH}_{4}$ concentrations as a first approximation of the dynamic relationships among these key atmospheric gases.

\section{Materials ANd Methods}

\section{Study Area}

This study was conducted in two forest types within the Luquillo Experimental Forest in northeastern Puerto Rico (Lat. $18^{\circ} 18^{\prime} \mathrm{N}$; Long. $65^{\circ} 50^{\prime} \mathrm{W}$ ), part of the NSF-sponsored Long Term Ecological Research Program. The lower elevation site $(350 \mathrm{~m}$ asl) was located in the Bisley Research Watersheds and occurs within lower montane wet tropical (Tabonuco) forest type. The upper elevation site $(930 \mathrm{~m}$ asl) was located in the cloud forest zone. These sites represent the lowermost and uppermost primary forest types along an elevation gradient of plant communities in Luquillo (Table 1; Brown and others 1983). The two study sites were located on relatively level topography. Both sites occur on highly weathered soils derived from volcaniclastic sediments: in Bisley the soils are ultisols and oxisols in the Cristal/Humatus/Zarzal complex whereas in the cloud forest the soils are classified as an inceptic Hapludox (oxisols, USDA NRCS 2002; Scatena 1989). Precipitation is relatively evenly distributed throughout the year ( $>200 \mathrm{~mm} / \mathrm{month})$ and increases from 3500 to $5000 \mathrm{~mm} \mathrm{y}^{-1}$ from Bisley to the cloud forest; mean annual temperature 
Table 1. Site Characteristics with Standard Errors in Parentheses

\begin{tabular}{|c|c|c|}
\hline & Bisley & Cloud Forest \\
\hline Life zone & $\begin{array}{l}\text { Subtropical } \\
\text { wet }\end{array}$ & $\begin{array}{l}\text { Lower Montane } \\
\text { rain }\end{array}$ \\
\hline Forest type & Tabonuco & Cloud \\
\hline Air temperature $\left({ }^{\circ} \mathrm{C}\right)$ & 21 & 19 \\
\hline Precipitation (mm) & 3500 & 5000 \\
\hline Total soil C (\%) & $3.1(0.07)$ & $16.0(0.05)$ \\
\hline Total soil nitrogen $(\%)$ & $0.27(0.005)$ & $0.70(0.027)$ \\
\hline Soil pH & $5.0(0.03)$ & $4.7(0.08)$ \\
\hline
\end{tabular}

Climate data are from Brown and others (1983) and Weaver and Murphy (1990).

decreases slightly with the altitude from $21^{\circ} \mathrm{C}$ at Bisley to $19^{\circ} \mathrm{C}$ in the cloud forest with little variability within sites throughout the year (Brown and others 1983; Weaver 1994).

\section{Field and Laboratory Methods}

Soil equilibration chambers were placed in the ground typically from 0.5 to $1 \mathrm{~m}$ from the nearest neighboring chamber. At the Bisley site, 14 chambers were located within an area of approximately $50 \mathrm{~m}^{2}$, whereas in the cloud forest site, the 15 chambers were installed over a larger area $\left(\sim 100 \mathrm{~m}^{2}\right)$ to avoid dense surficial roots. The chambers were $15 \mathrm{~cm}$ long and constructed of $5 \mathrm{~cm}$ diameter polyvinyl chloride (PVC) pipe, open on the bottom and capped on top. To insert the chambers, $10 \mathrm{~cm}$ of soil was removed with a metal corer of similar diameter and chambers were pushed into the hole an additional $5 \mathrm{~cm}$ so that the cap was just below the soil surface. Thus, the chambers contained $10 \mathrm{~cm}$ of headspace over $5 \mathrm{~cm}$ of soil. Oxygen sensors (Apogee Instruments, Logan, UT) were suspended inside the headspace of the chambers. The chamber tops were fitted with copper tubing with a three-way stopcock for trace gas sampling. Cable and tubing connections were thoroughly coated with automotive Goop (Eclectic Products, Eugene, OR) to create an airtight seal. The removed soil was used to backfill the small gap between the chamber and the surrounding intact soil. The chambers were sampled for 5 months in Bisley and 9 months in the cloud forest. The time period allowed for sufficient replication of withinsite temporal variability in soil $\mathrm{O}_{2}$ concentrations needed to identify trends in both sites. To collect samples for trace gas $\left(\mathrm{CO}_{2}, \mathrm{CH}_{4}\right.$, and $\left.\mathrm{N}_{2} \mathrm{O}\right)$ analysis, a $30-\mathrm{ml}$ sample was extracted from the chamber with a polypropylene syringe and injected into a sealed, pre-evacuated $20 \mathrm{ml}$ Wheaton vial. Soil $\mathrm{O}_{2}$ data were collected hourly using a data logger (CR1000) and multiplexer (AM16/32) (Campbell Scientific, Logan, UT). Trace gas sampling occurred weekly in Bisley $(n=8)$ and approximately biweekly $(n=19)$ in the cloud forest.

The chambers were allowed to equilibrate with the surrounding soil atmosphere. In Bisley, this process lasted only a few days for most sensors. Average soil $\mathrm{O}_{2}$ concentrations were much lower in the cloud forest and for almost half of the chambers, soil $\mathrm{O}_{2}$ decreased over 3-4 weeks (polynomial fit $R^{2}>0.9$ ) before reaching equilibration. The measurements during this transitory period were excluded in subsequent analyses. In Bisley, an additional gap of a week was due to a battery failure. In the cloud forest site, $\mathrm{O}_{2}$ concentrations were occasionally observed to change following trace gas sampling, typically an increase of less than $1 \%$ oxygen. All the chambers were affected at least once during the sampling, but some chambers were more susceptible than others. The data when affected by trace gas sampling were removed from the analysis until the signal re-equilibrated, typically from 1 to 3 days.

\section{Data Analysis}

Differences in gas concentrations among sites were tested with one-way analysis of variance (ANOVA) with mean values from the individual chambers as replicates. Relationships among gas concentrations were examined with correlation and regression analyses with individual samples from chambers as replicates. Data were log transformed as needed to meet the distributional requirements of the statistical tests. Wavelet analysis was performed to explore the temporal variability of $\mathrm{O}_{2}$ time series and their relationship with climate drivers. This spectral technique, analogous to Fourier analysis, breaks up the process variance into pieces, each of which represents the contribution on a particular scale (Cazelles and others 2008). The wavelet transformation of a discrete signal $x_{n}$ (or hits $n$-order stationary increment) of length $N$ recorded at $\delta \mathrm{t}$ interval, is defined as the convolution integral (Lau and Weng 1995; Torrence and Compo 1998):

$$
W_{n}(s)=\left(\frac{\delta t}{s}\right)^{1 / 2} \sum_{n^{\prime}=0}^{N-1} x_{n^{\prime}} \psi_{0}^{*}\left(\frac{n-n^{\prime}}{s / \delta t}\right)
$$

where $\psi_{0}^{*}$ is the complex conjugate of the scaled and translated mother wavelet, and $s$ is the wavelet scale at which the transformation is applied. The continuous wavelet transformation is calculated by continuously shifting the scale and time in 
equation (1). The wavelet power spectrum (WPS), is then computed as $\operatorname{WPS}_{n}(s)=W_{n}(s) W_{n}^{*}(s)$. Analogously, the wavelet co-spectrum (WCS) between two time series $x_{n}$ and $y_{n}$ is defined as $\mathrm{WCS}_{n}^{x, y}(s)=W_{n}^{x}(s) W_{n}^{y *}(s)$. The global wavelet power spectra, the analog of Fourier spectra, are the time average of WPS (or WCS):

$$
\begin{gathered}
S_{x x}(s)=\frac{1}{n} \sum_{n=1}^{n} \operatorname{WPS}_{n}^{x}(s) \\
S_{x y}(s)=\frac{1}{n} \sum_{n=1}^{n} \operatorname{WCS}_{n}^{x, y}(s)
\end{gathered}
$$

These quantities can be combined to form the wavelet magnitude square coherence, or simply wavelet coherence WC:

$$
\mathrm{WC}=\frac{\left|\left\langle S_{x y}\right\rangle\right|^{2}}{\left\langle S_{x x}\right\rangle\left\langle S_{y y}\right\rangle}
$$

where the angular brackets indicate ensemble averages if multiple realizations of $x$ or $y$ are available. WC can be thought of as the spectral correlation between two time series and, equivalent to the $R^{2}$, can vary between 0 and 1 . Importantly, WC finds regions in the frequency space where two time series co-vary, but do not necessarily have high common power (Cazelles and others 2008; Grinsted and others 2004; Yates and others 2007). The use of a complex wavelet in this analysis also allows for exploration of the phase difference between the two time series evaluated as $\tan ^{-1}\left[\Im\left\{W C S^{x y}(s)\right\} / \Re\left\{W C S^{x y}(s)\right\}\right]$.

The hourly $\mathrm{O}_{2}$ series were numerically differentiated $\left(\mathrm{dO}_{t}=\mathrm{O}_{t}-\mathrm{O}_{t-1}\right)$ to reduce non-stationarity. Physically, these differences represent the time series of $\mathrm{O}_{2}$ losses or gains by the soil in $1 \mathrm{~h}$ time intervals. The hourly climate (temperature and precipitation) data for the two sites were provided by the LTER and USDA Forest Service long-term climate monitoring program (F. Scatena for Bisley and W. Silver for cloud forest, available at http://luq.lternet.edu/data). For Bisley all the $\mathrm{O}_{2}$ chambers were used in this analysis. For the cloud forest chambers with many missing data were excluded $(n=3)$, as were chambers with little temporal fluctuation over the study period, yielding a sample size of five chambers. Thus, the time series evaluated at the cloud forest site were only from the chambers sensitive to environmental fluctuation and may not be indicative of how the entire site responds to climate. A 95\% confidence level for the WC was obtained through Monte Carlo Simulation using 1,000 surrogates (Palus 2008).

\section{Results}

The mean $\mathrm{O}_{2}$ concentration in Bisley $(7.9 \pm 1.1 \%)$ was significantly higher than in the cloud forest $(3.0 \pm 0.8 \%) \quad\left(F_{1,27}=9.2, P=0.005\right)$. In Bisley, the chambers varied in $\mathrm{O}_{2}$ concentrations over time and space with some relatively oxic, and some relatively anoxic, but about half experienced an almost equal probability of $\mathrm{O}_{2}$ concentrations from $0-19 \%$ (Figure 1A). In the cloud forest, in contrast, most of the chambers were relatively anoxic, as nine of the 15 sensors remained below $1 \% \mathrm{O}_{2}$ the entire sampling period (Figure 1B). The distribution of hourly measurements in the cloud forest site was strongly skewed to anoxic conditions, with soil $\mathrm{O}_{2}$ concentrations less than $1 \%$ almost $60 \%$ of the measurement period (Figure 2). In contrast, the overall distribution of soil $\mathrm{O}_{2}$ across sensors over time was strikingly uniform.

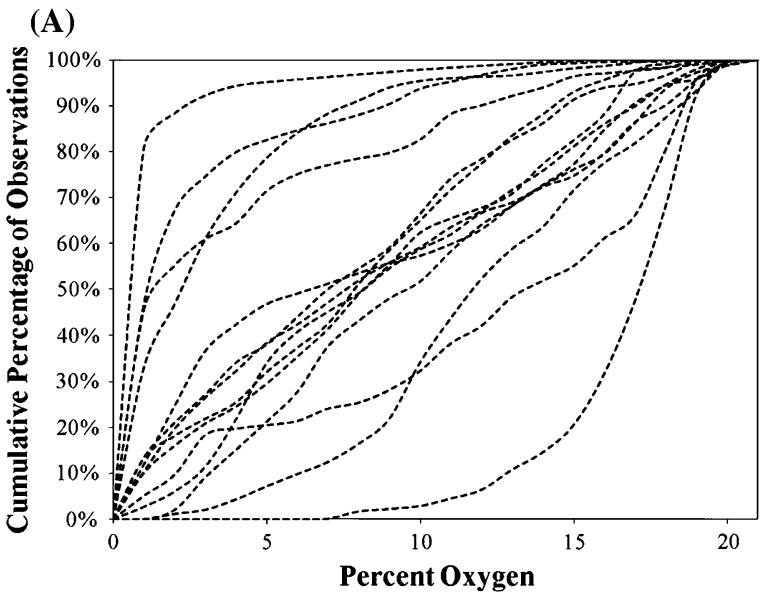

(B)

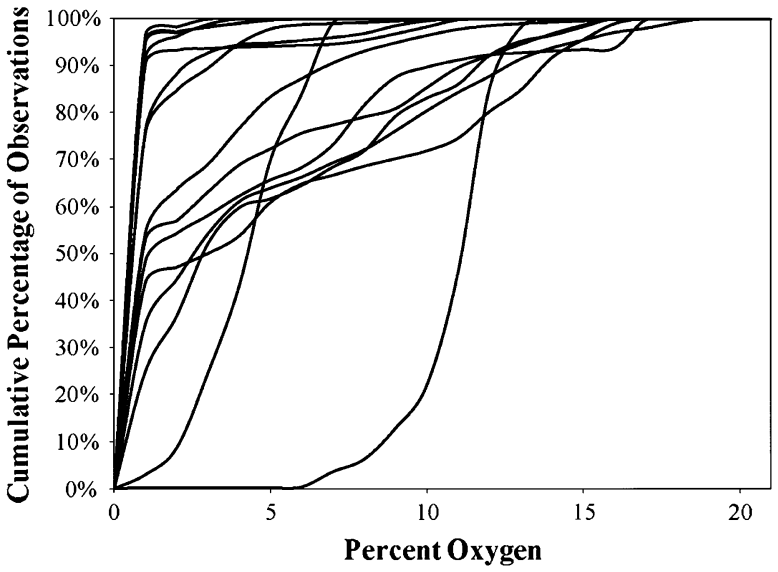

Figure 1. The cumulative percent of observations of soil $\mathrm{O}_{2}$ concentrations ranging from $0-21 \%$ from buried equilibration chambers in Bisley $(\mathbf{A})$ and the cloud forest sites $(\mathbf{B})$. 


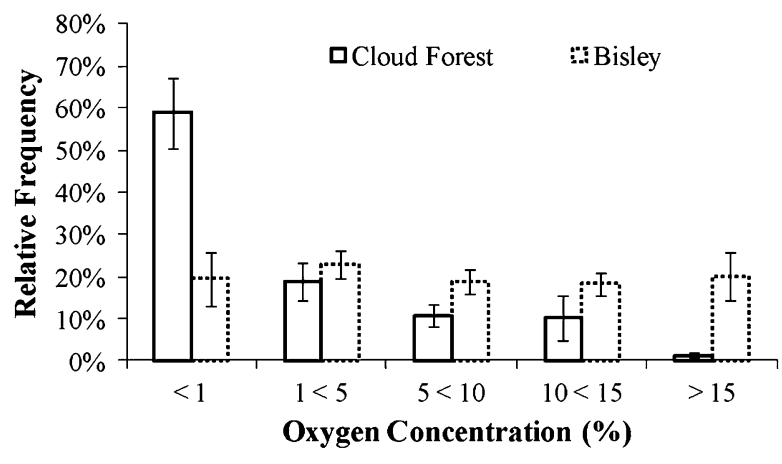

Figure 2. Relative frequency of hourly soil $\mathrm{O}_{2}$ concentrations in buried soil equilibration chambers in Bisley and the cloud forest sites.

The global WPS for $\mathrm{O}_{2}$ suggested periodicity in $\mathrm{O}_{2}$ concentration of 8 to 60 days, with a prominent peak located at 16 days at Bisley. The chambers that fluctuated in the cloud forest showed a broader energetic band at periods greater than 7 days. The global WPS for precipitation exhibited periodicity between 3 and 30 day periods, with considerable energy at lower frequencies (more evident in the longer record at the cloud forest site). At higher frequencies, the precipitation and $\mathrm{O}_{2}$ spectra had similar power law decay at both sites (Figure 3A). The prominent peak for the temperature spectrum, occurring at a period of 1 day, was absent from the $\mathrm{O}_{2}$ and precipitation spectra. These results suggest that precipitation, more than temperature, may be responsible for the temporal dynamics of soil $\mathrm{O}_{2}$.

Based on the similarities in the spectra, we examined the WC between the $\mathrm{O}_{2}$ and precipitation time series (Figure 4). At the Bisley site, there was significant coherence $(0.25-0.35)$ in the region of maximum energy for $\mathrm{O}_{2}$, at periods of 4-25 days. The average phase difference was $-153^{\circ}$ for periods of 3-20 days, indicating that an increase of precipitation corresponded to a decrease in $\mathrm{O}_{2}$. The approximately antiphase relationship of the two time series resulted in increases in $\mathrm{O}_{2}$ concentrations during rain-free days with an inflection point after a rainfall event and decreases in $\mathrm{O}_{2}$ concentrations during wet periods with the trough in the $\mathrm{O}_{2}$ time series occurring when the rainfall ceased. For example, a 12 day fluctuation involved a 5-day dry period with increasing $\mathrm{O}_{2}$ concentrations, followed by a 7-day wet period with declining $\mathrm{O}_{2}$ concentrations.

Several time periods with more than 4 consecutive dry ( $<1 \mathrm{~mm}$ rainfall) days occurred during the sampling period in Bisley. For example, during the dry period from DOY 88-93, essentially all of the sensors increased in $\mathrm{O}_{2}$ with almost simultaneous inflection points when a rain event occurred on DOY 93 (Figure 5A). There were fewer instances of long dry periods in the cloud forest, and the coherence between $\mathrm{O}_{2}$ and precipitation was only significant at periods of about 2 days. The only dry period longer than 4 days in length during the measurement period in the cloud forest was associated with increases in $\mathrm{O}_{2}$ in only four of the sensors (Figure 5B). In general, there were more dry days and the dry periods persisted longer in Bisley compared to the cloud forest site (Table 2). The longest dry period during 2007-2008 lasted for 12 days and occurred at both sites.
(A)

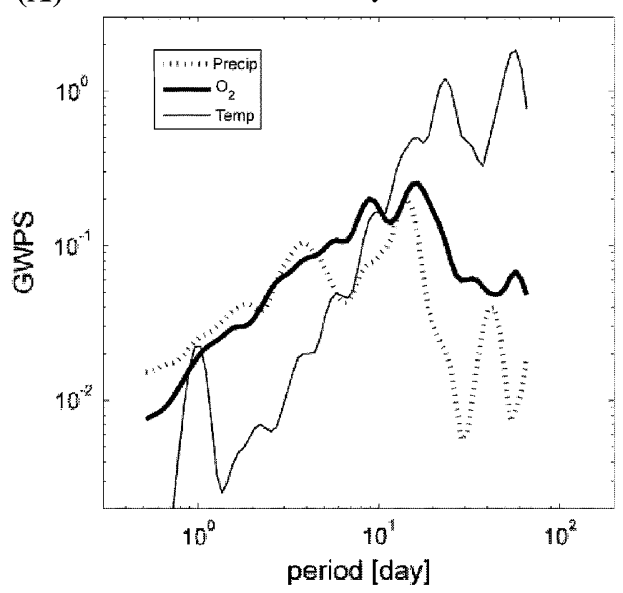

(B)

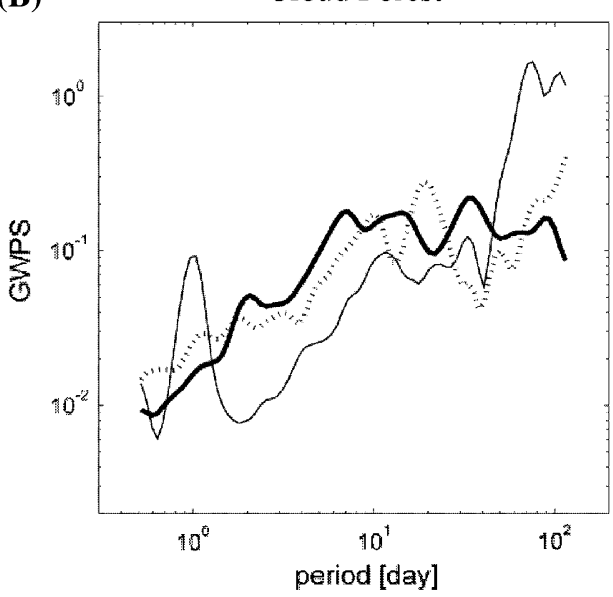

Figure 3. Global wavelet power spectra (GWPS) for hourly chamber $\mathrm{O}_{2}$, air temperature, and precipitation at Bisley (A) and the cloud forest (B) sites. The lines represent the power of the spectra at a range of periodicities. Only temperature displays a strong periodicity at daily $\left(10^{\circ}\right)$ time scales whereas precipitation and $\mathrm{O}_{2}$ exhibit the greatest power in the spectra at periods of $1-2$ weeks. 

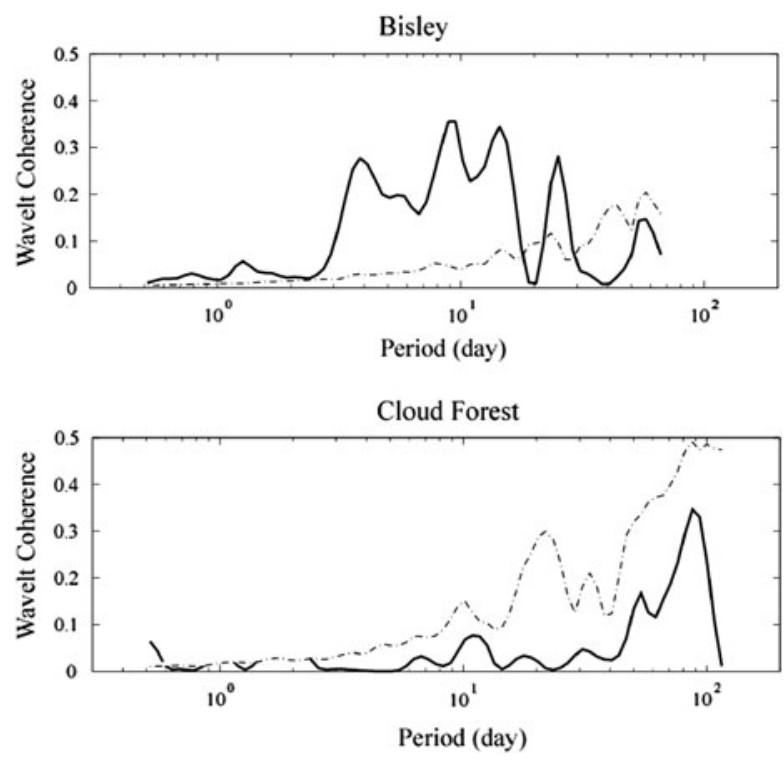

Figure 4. Global wavelet coherence for hourly chamber $\mathrm{O}_{2}$ and precipitation at Bisley and cloud forest sites. Dashed lines represent the $95 \%$ confidence interval such that higher values represent significant coherence between the $\mathrm{O}_{2}$ and precipitation time series.
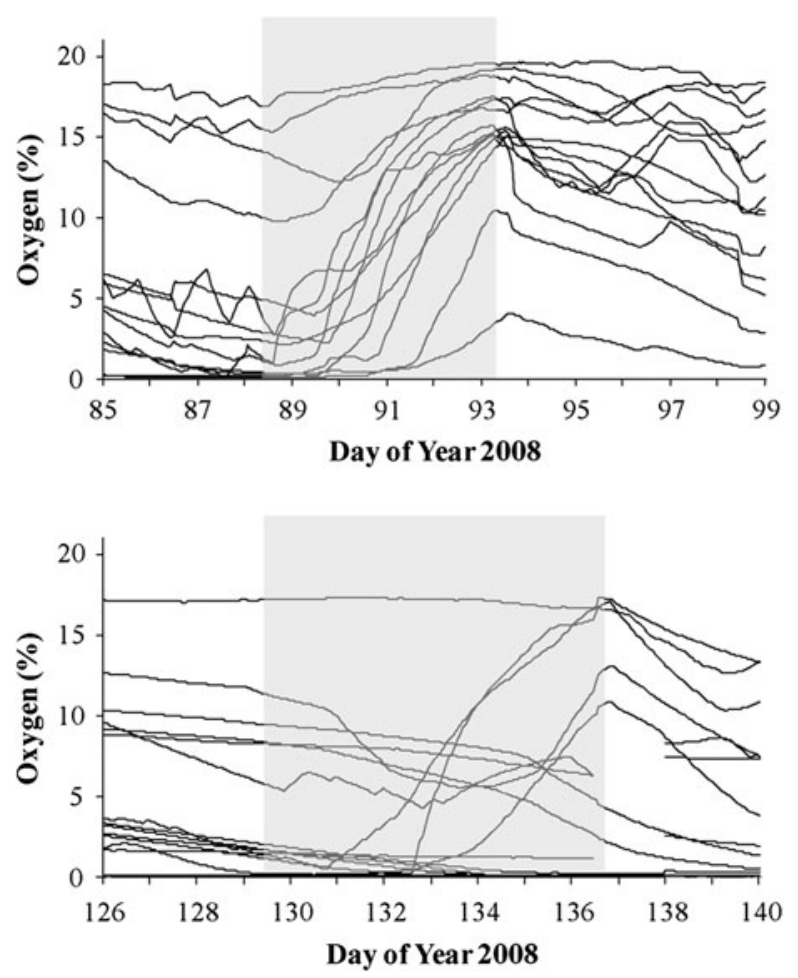

Figure 5. The response of soil oxygen to dry periods in Bisley (A) and cloud forest (B) with the period of less than $1 \mathrm{~mm}$ rainfall per day shaded in gray.

The sites differed significantly in trace gas concentrations. Concentrations of $\mathrm{N}_{2} \mathrm{O}$ were higher and $\mathrm{CO}_{2}$ and $\mathrm{CH}_{4}$ were lower in Bisley than in the
Table 2. Frequency of Dry Periods (Consecutive Days with Less than $1 \mathrm{~mm}$ Rainfall) at Bisley and Cloud Forest Sites for 2007 and 2008 Encompassing the Study Period for Both Forest Types

\begin{tabular}{lccccc}
\hline $\begin{array}{l}\text { Length of dry } \\
\text { period (days) }\end{array}$ & \multicolumn{2}{l}{ Bisley } & & \multicolumn{2}{c}{ Cloud } \\
\cline { 2 - 3 } \cline { 5 - 6 } & 2007 & $\mathbf{2 0 0 8}$ & & $\mathbf{2 0 0 7}$ & $\mathbf{2 0 0 8}$ \\
\hline 1 & 32 & 36 & 24 & 41 \\
2 & 7 & 16 & 8 & 9 \\
3 & 9 & 10 & & 8 & 5 \\
4 & 3 & 4 & & 1 & 3 \\
5 & 0 & 1 & 0 & 0 \\
6 & 0 & 0 & & 1 & 1 \\
7 & 1 & 0 & 0 & 0 \\
8 & 1 & 0 & & 0 & 0 \\
9 & 1 & 1 & & 0 \\
10 & 0 & 0 & 0 & 0 \\
11 & 1 & 0 & 0 & 0 \\
12 & 1 & 0 & 1 & 0 \\
\hline
\end{tabular}

Table 3. Mean (+l SE) Chamber Gas Concentrations by Site Calculated from Chamber Averages ( $n=14$ Bisley, $n=15$ Cloud Forest)

\begin{tabular}{lrc}
\hline & \multicolumn{1}{c}{ Bisley } & Cloud Forest \\
\hline $\mathrm{O}_{2}$ overall $(\%)$ & $7.9(1.1)$ & $3.0(0.8)$ \\
$\mathrm{O}_{2}$ sampling $(\%)$ & $9.3(1.4)$ & $3.3(0.8)$ \\
$\mathrm{CO}_{2}(\%)$ & $6.7(0.6)$ & $9.2(1.0)$ \\
$\mathrm{N}_{2} \mathrm{O}(\mathrm{ppm})$ & $23.0(5.4)$ & $0.3(0.1)$ \\
$\mathrm{CH}_{4}(\mathrm{ppm})$ & $1.7(0.2)$ & $771.7(802.7)$
\end{tabular}

$\mathrm{O}_{2}$ overall is the average of the entire sampling period and $\mathrm{O}_{2}$ sampling is the mean of the concentrations when the trace gas sampling was done. All of the site differences are significantly different $(P<0.05)$.

cloud forest with almost no overlap of values between sites for $\mathrm{N}_{2} \mathrm{O}$ and $\mathrm{CH}_{4}$ (Table 3). The cumulative probability distributions differed both among trace gases and among sites (Figure 6). The soil $\mathrm{CO}_{2}$ concentrations were in the percent range at both sites. Although the range of concentrations differed between sites, there was a relatively even distribution at both sites. The shape of the $\mathrm{N}_{2} \mathrm{O}$ distribution was also similar between sites. Whereas $\mathrm{N}_{2} \mathrm{O}$ was sometimes not detectable in the cloud forest soils, at Bisley the concentrations were always greater than atmospheric concentrations ( $320 \mathrm{ppb}$ ). Both the shape and the range of the distribution of $\mathrm{CH}_{4}$ differed among sites. There was a relatively narrow range of $\mathrm{CH}_{4}$ concentrations in Bisley, typically near or below atmospheric concentrations $(\sim 1.8 \mathrm{ppm})$, but reaching as high as $68 \mathrm{ppm}$. There was a much wider range in $\mathrm{CH}_{4}$ 

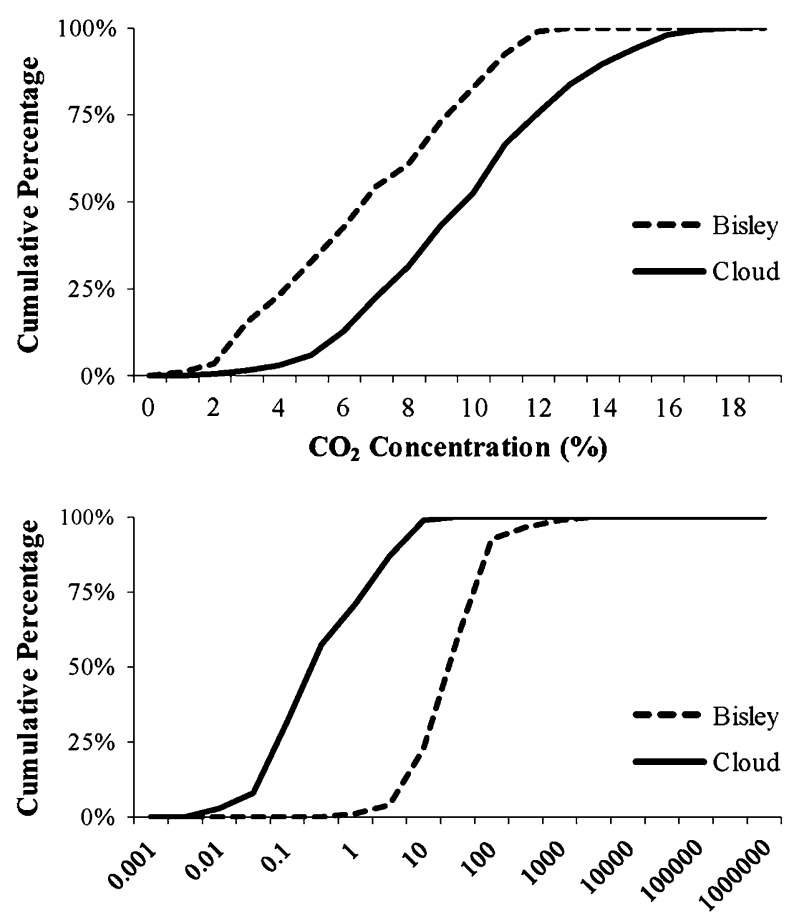

$\mathrm{N}_{2} \mathrm{O}$ Concentration (ppm)

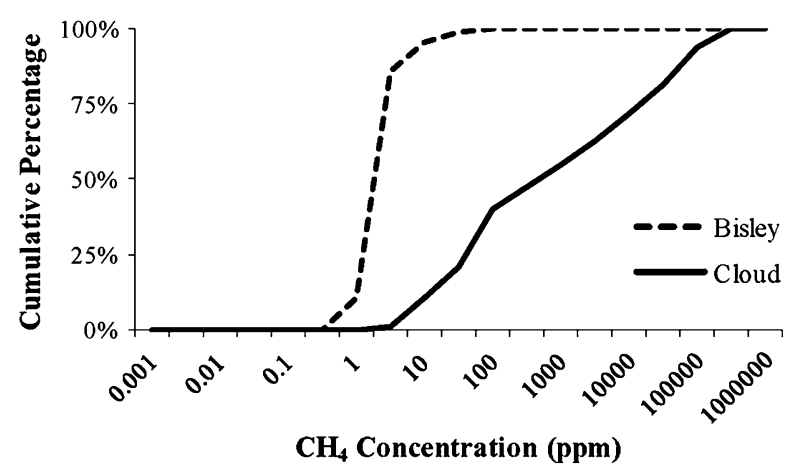

Figure 6. The cumulative percent of all observations of the trace gases $\mathrm{CO}_{2}, \mathrm{CH}_{4}$, and $\mathrm{N}_{2} \mathrm{O}$.

concentrations at the cloud forest site with concentrations spanning from $1.3 \mathrm{ppm}$ up to $17 \%$.

There were significant relationships among the concentrations of the four gases measured. The correlation between $\mathrm{O}_{2}$ and $\mathrm{N}_{2} \mathrm{O}$ was positive as was the correlation between $\mathrm{CO}_{2}$ and $\mathrm{CH}_{4}$. Both $\mathrm{O}_{2}$ and $\mathrm{N}_{2} \mathrm{O}$ were negatively correlated with $\mathrm{CO}_{2}$ and $\mathrm{CH}_{4}$ (Table 4). Across both the sites, we found a strong negative correlation between $\mathrm{N}_{2} \mathrm{O}$ and $\mathrm{CH}_{4}$, but the concentrations of these gases also depended on $\mathrm{O}_{2}$ concentrations. When $\mathrm{O}_{2}$ concentrations were less than $1 \%, \mathrm{~N}_{2} \mathrm{O}$ concentrations were generally at or below atmospheric concentrations and $\mathrm{CH}_{4}$ was generally above $50 \mathrm{ppm}$ and often above $1 \%$ (Figure 7). Although soil $\mathrm{CO}_{2}$ concentrations were on average higher at the cloud forest site, the
Table 4. Correlation Coefficients $(r)$ Among all Soil Gases Within Buried Equilibration Chambers with Data Combined from Both Sites

\begin{tabular}{|c|c|c|c|c|}
\hline & $\mathrm{O}_{2}$ & $\mathrm{CH}_{4}$ & $\mathrm{CO}_{2}$ & $\mathrm{~N}_{2} \mathrm{O}$ \\
\hline $\mathrm{O}_{2}$ & 1 & -0.60 & -0.69 & 0.62 \\
\hline $\mathrm{CH}_{4}$ & -0.60 & 1 & 0.62 & -0.85 \\
\hline $\mathrm{CO}_{2}$ & -0.69 & 0.62 & 1 & -0.57 \\
\hline $\mathrm{N}_{2} \mathrm{O}$ & 0.62 & -0.85 & -0.57 & 1 \\
\hline
\end{tabular}

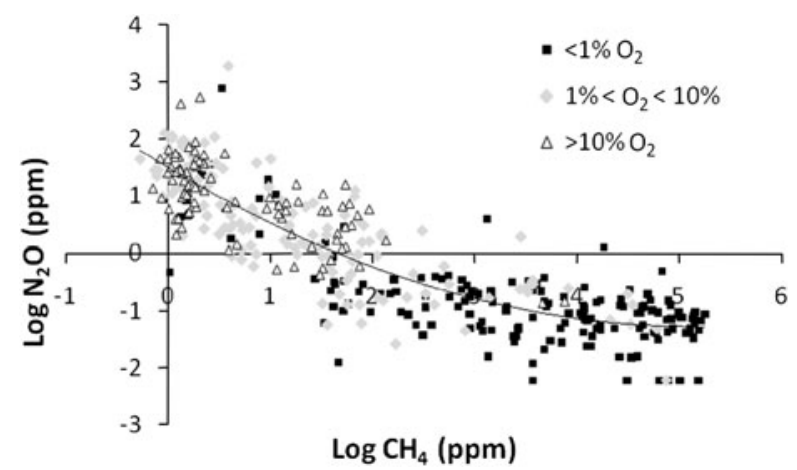

Figure 7. Relationship between $\mathrm{N}_{2} \mathrm{O}$ and $\mathrm{CH}_{4}$ across sites as related to $\mathrm{O}_{2}$ concentration.

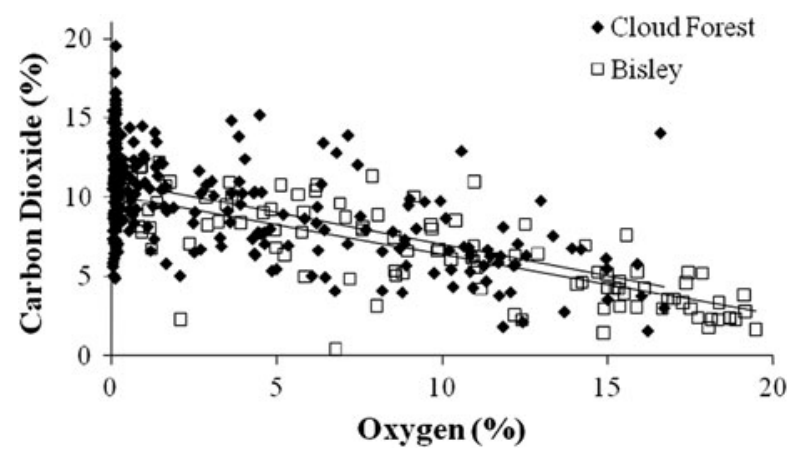

Figure 8. Relationship between $\mathrm{CO}_{2}$ and $\mathrm{O}_{2}$ for both sites. Each point represents an individual sample from a buried equilibration chamber. The best fit linear relationship between $\mathrm{O}_{2}$ and $\mathrm{CO}_{2}$ is $\mathrm{CO}_{2}=-0.40 * \mathrm{O}_{2}+$ 11.0, $R^{2}=0.31, P<0.001$ for the cloud forest and $\mathrm{CO}_{2}=-0.38 * \mathrm{O}_{2}+10.2, R^{2}=0.60, P<0.001$.

relationship between $\mathrm{CO}_{2}$ and $\mathrm{O}_{2}$ was almost identical for the two sites with $\mathrm{CO}_{2}=-0.38$ * $\mathrm{O}_{2}+10.2\left(R^{2}=0.6, \quad P<0.0001\right)$ for Bisley and $\mathrm{CO}_{2}=-0.4 * \mathrm{O}_{2}+11.0\left(R^{2}=0.3, P<0.0001\right)$ for the cloud forest (Figure 8). To highlight the general trends in relationships of the trace gases and $\mathrm{O}_{2}$, we created 10 equal size bins based on $\mathrm{O}_{2}$ concentration for the entire trace gas dataset. This approach highlights the strong negative linear relationship with $\mathrm{CO}_{2}$, as well as the strong negative non-linear 


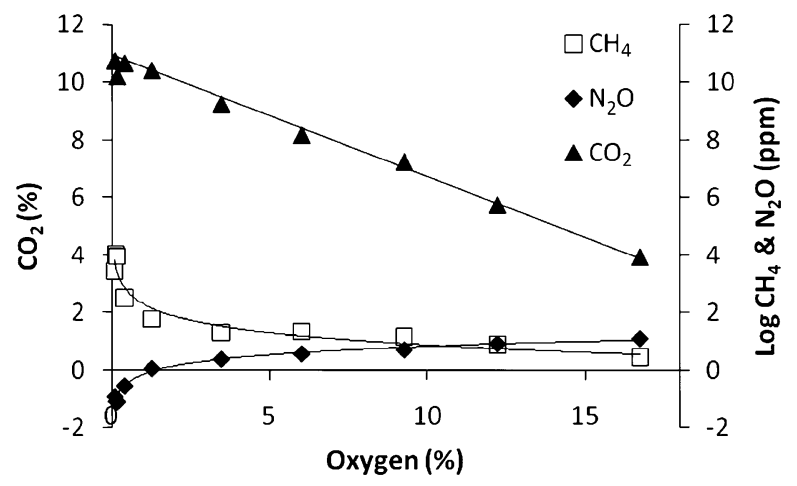

Figure 9. Overall relationship between $\mathrm{O}_{2}$ and trace gases. The values were divided into ten equal size bins by $\mathrm{O}_{2}$ concentration and a median trace gas concentration is shown for each bin.

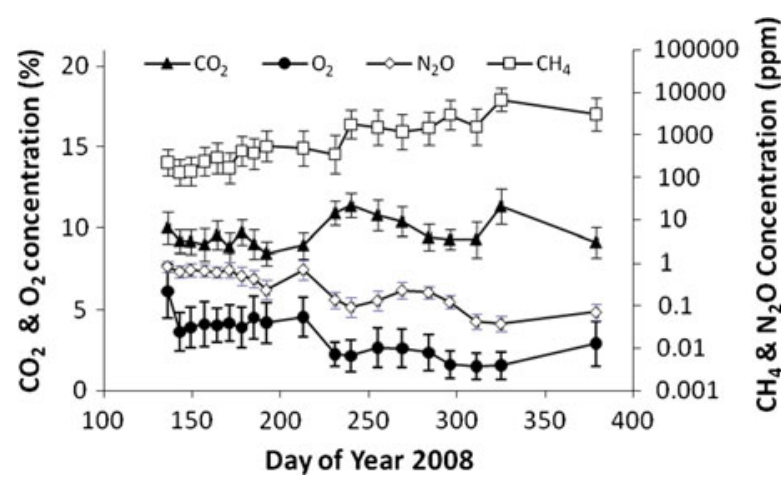

Figure 10. Temporal dynamics of trace gases and oxygen from buried equilibration chambers for the cloud forest site.

and positive nonlinear relationships with $\mathrm{CH}_{4}$ and $\mathrm{N}_{2} \mathrm{O}$ (Figure 9). The overall temporal trends in trace gases were weak, especially compared to the spatial variability. In the cloud forest, there were some general trends over time with $\mathrm{O}_{2}$ and $\mathrm{N}_{2} \mathrm{O}$ decreasing and $\mathrm{CH}_{4}$ increasing (Figure 10).

\section{Discussion}

\section{Soil $\mathrm{O}_{2}$}

The effects of $\mathrm{O}_{2}$ depletion on the biogeochemistry of flooded soils have been well documented (for example, Gambrell and Patrick 1978; Ponnamperuma 1972), but little is known about the frequency and importance of anoxia in upland soils. Our results suggest that oxic conditions are not the norm for these wet tropical forest soils. In many parts of the cloud forest site, the soils remained anoxic for months at a time, more similar to wetland environments. This is not surprising given that the ecosystem exhibits characteristics of low $\mathrm{O}_{2}$ environments like sub-aerial roots (Weaver and others 1986), high soil organic matter content (Silver and others 1999; McGroddy and Silver 2000), and low net primary productivity (Weaver and Murphy 1990). In Bisley, most of the chambers experienced anoxia at some point, but overall the cumulative distribution of $\mathrm{O}_{2}$ concentrations was relatively uniform. That is, across the whole sampling period and across all sensors there was essentially an equal probability of any $\mathrm{O}_{2}$ concentration between 0 and $21 \%$ (atmospheric $\mathrm{O}_{2}$ ). Spatial variability was also high as $\mathrm{O}_{2}$ concentrations in chambers located just meters apart could be positively or negatively correlated or uncorrelated with each other.

The temporal dynamics in soil $\mathrm{O}_{2}$ were strongly associated with the frequency, but not necessarily the amount, of precipitation. Soil $\mathrm{O}_{2}$ concentrations rose during dry periods and fell during rainy periods. These fluctuations in $\mathrm{O}_{2}$ concentrations were especially prominent during dry periods lasting several days, suggesting strong nonlinear dynamics. Although the number and length of dry periods were greater in Bisley than in the cloud forest, long dry periods (typically 5-8 days) were accompanied by rising $\mathrm{O}_{2}$ concentration in both sites. Soil $\mathrm{O}_{2}$ concentrations dropped very rapidly (within a few hours) after even relatively small rainfall events $(\sim 1 \mathrm{~mm})$, but would only continue dropping if the rainfall continued. During periods with consistent daily rainfall $\mathrm{O}_{2}$ concentrations still varied, but not in conjunction with the amount of precipitation. The strongest periodicities in the WPS were from 10 to 16 days in Bisley consistent with the observed cycles of dry and wet periods. The frequency of these dry periods varied spatially and temporally in these forests. For example, the total number of days without $(<1 \mathrm{~mm})$ rain was higher in 2008 than 2007 at both sites. However, in 2008 the dry periods tended to be shorter ( 3 days or fewer in length) with no long dry periods in the cloud forest. In contrast, in 2007, there were several time periods of at least a week with no rain in the cloud forest $(n=3)$ and Bisley $(n=5)$ (F. Scatena, personal communication). If climate change alters the precipitation patterns such that dry periods become more common, an increase in the frequency and magnitude of redox fluctuations would be likely, especially at the cloud forest site. Likewise, if climate change results in wetter climates, the soils could experience more prolonged periods of low $\mathrm{O}_{2}$ and greater $\mathrm{CH}_{4}$ concentrations.

Soil $\mathrm{O}_{2}$ concentrations reflect the net balance of $\mathrm{O}_{2}$ supply and demand based on physical processes 
and biological activity. The rapidity of the response of soil $\mathrm{O}_{2}$ concentrations to precipitation events suggests that the physical processes, such as the displacement of air by water in soil pore spaces, dominate. However, biological processes could play a role as well. In tropical rain forest soils, C mineralization may be governed by dissolved organic matter leaching from the litter into the soil (Cleveland and Townsend 2006). Thus, without rainfall, $\mathrm{C}$ availability and $\mathrm{O}_{2}$ demand may actually decline. Experiments manipulating water and $\mathrm{C}$ availability simultaneously could help separate these two effects.

Plants also affect and are affected by soil redox conditions. At the ecosystem level, the plant community is often less diverse in highly anoxic environments. In Luquillo, the cloud forest canopy is entirely dominated by just five species with just a small fraction of the number of tree species present at lower elevations (Weaver and others 1986; Weaver and Murphy 1990). Special structures, like aerenchymatous tissue, pneumatophores, lenticels, stilt roots help plants survive the various types of low redox environments ranging from high elevation cloud forests to coastal mangrove swamps (Benzing 1991). At smaller spatial scales, plants also actively influence redox-sensitive processes. Plants alter the chemical environment in the rhizosphere affecting the rates of mineral weathering and nutrient cycling (Fimmen and others 2008; Weiss and others 2005). The physical structure of plants can increase the emissions of gases, in particular methane, from anoxic soils, to the atmosphere (Cicerone and Shetter 1981).

\section{Trace Gases}

The concentrations of trace gases differed significantly between the two sites, but their relationships with $\mathrm{O}_{2}$ were similar. The average $\mathrm{N}_{2} \mathrm{O}$ concentrations were an order of magnitude higher in Bisley compared to the cloud forest. Nitrous oxide was typically higher than atmospheric levels in Bisley suggesting net production in the soil. At the cellular level, $\mathrm{N}_{2} \mathrm{O}$ production and consumption are thought to be controlled by the availability of $\mathrm{O}_{2}$, nitrate, and organic $\mathrm{C}$ (Firestone and Davidson 1989). In soils, $\mathrm{N}_{2} \mathrm{O}$ is predicted to be the most common product of nitrification and dentrification at intermediate soil moisture with soil moisture as a proxy for soil $\mathrm{O}_{2}$ (Davidson and others 2000). In this study, it was somewhat unexpected to see $\mathrm{N}_{2} \mathrm{O}$ concentrations increase monotonically with $\mathrm{O}_{2}$, such that $\mathrm{N}_{2} \mathrm{O}$ concentrations were highest at near atmospheric $\mathrm{O}_{2}$ concentrations. This differs from the unimodal $\mathrm{N}_{2} \mathrm{O}-\mathrm{O}_{2}$ relationship observed along a soil catena in the adjacent Icacos watershed in Puerto Rico (McSwiney and others 2001). These authors found $\mathrm{N}_{2} \mathrm{O}$ concentrations were highest at intermediate $\mathrm{O}_{2}$ concentrations. If $\mathrm{N}_{2} \mathrm{O}$ was produced during denitrification, it would have been occurring in anaerobic microsites in Bisley under the more oxic conditions. Because the soils were often relatively oxic, nitrification could also be an important source of $\mathrm{N}_{2} \mathrm{O}$ (Bollmann and Conrad 1998). In the cloud forest, where soil $\mathrm{O}_{2}$ was consistently very low, denitrification to $\mathrm{N}_{2}$ was likely to be more important. The measured $\mathrm{N}_{2} \mathrm{O}$ concentrations were lower than background atmospheric levels which suggest consumption of atmospheric $\mathrm{N}_{2} \mathrm{O}$.

Methane concentrations were on average more than three orders of magnitude larger in the cloud forest soils than in Bisley, but as with $\mathrm{N}_{2} \mathrm{O}$ the relationship between $\mathrm{O}_{2}$ and $\mathrm{CH}_{4}$ was similar across sites. In both sites, the relationship between $\mathrm{O}_{2}$ and $\mathrm{CH}_{4}$ was strongly nonlinear. High methane concentrations (that is, $>1 \%$ ) were only observed when bulk soil $\mathrm{O}_{2}$ was less than $1 \%$, but these high concentrations were quite common. The $\mathrm{O}_{2}$ concentrations were low and relatively static in the cloud forest soils. This persistent anoxia appears to have resulted in considerable methanogenesis. Although the current study only quantified concentrations of $\mathrm{CH}_{4}$, others have measured net $\mathrm{CH}_{4}$ efflux from similar sites in Bisley and the cloud forest (Silver and others 1999; Teh and others 2005).

Carbon dioxide concentrations were much less variable between sites than the other greenhouse gases, but like the others, soil $\mathrm{O}_{2}$ was a strong predictor of $\mathrm{CO}_{2}$ concentrations. Theory would predict a 1:1 $\mathrm{M}$ relationship of $\mathrm{CO}_{2}$ production and $\mathrm{O}_{2}$ consumption during organic $\mathrm{C}$ mineralization to $\mathrm{CO}_{2}$ with $\mathrm{O}_{2}$ as the dominant electron acceptor. This is not always observed in the field, however (Teh and others 2005; Iiyama and Hasegawa 2009), and was not observed here. The relationship could vary from the predicted 1:1 relationship because there are other processes in soils besides aerobic $\mathrm{C}$ mineralization that could result in $\mathrm{CO}_{2}$ production (for example, heterotrophic denitrification, $\mathrm{Fe}$ reduction, methanotrophy, acetoclastic methanogenesis) or consumption (hydrogenotrophic methanogenesis) as well as geochemical reactions and root activity that can produce and consume $\mathrm{O}_{2}$ or $\mathrm{CO}_{2}$ in the soil. The slope of the observed $\mathrm{O}_{2}-\mathrm{CO}_{2}$ relationship in this study was much shallower than -1 . If $\mathrm{CO}_{2}$ production from alternative electron acceptors were contributing, the slope would be 
steeper. The lack of a 1:1 relationship may be due to the relatively high soil moisture content typical of these soils combined with high biological activity. A significant fraction of the total $\mathrm{CO}_{2}$ may be dissolved in the soil water instead of in air-filled pores. The Henry's law constant is 27 times higher for $\mathrm{CO}_{2}$ than $\mathrm{O}_{2}$ (Gevantman 2010) thus the slope of the $\mathrm{O}_{2}-\mathrm{CO}_{2}$ relationship should be shallower than -1 , but will depend on the proportion of water-filled pore space (WFPS): as WFPS increases, the slope of the relationship becomes increasingly shallow because relatively more $\mathrm{CO}_{2}$ will be in solution compared to $\mathrm{O}_{2}$. At the end of the study period, the WFPS calculated following Elliott and others (1999) was 70\% in Bisley, based on a gravimetric water content of $73 \%$ and a bulk density of 0.7 (Silver and others 1994). Using these values and Henry's law predicts a slope of -0.36 , almost identical to the observed regression slope -0.38 . Some of the scatter around the regression line may be associated with changes in soil moisture which would change the slope of the relationship even without changes in production or consumption of either gas.

The strong negative relationship between $\mathrm{CO}_{2}$ and $\mathrm{O}_{2}$ concentrations in soils does not necessarily translate into higher $\mathrm{CO}_{2}$ fluxes in low $\mathrm{O}_{2}$ environments. Surface fluxes are the net balance of consumption, production, and transport of $\mathrm{CO}_{2}$. High soil $\mathrm{CO}_{2}$ concentrations may be the result of slow diffusion if most soil pores are filled with water during low $\mathrm{O}_{2}$ conditions. When other high and low $\mathrm{O}_{2}$ sites in the same watershed were compared, the high $\mathrm{O}_{2}$ site had higher surface fluxes (Teh and others 2005). However, when Luquillo soils were incubated in the lab, $\mathrm{CO}_{2}$ production did not vary significantly between oxic and anoxic treatments suggesting that anoxia per se does not limit $\mathrm{C}$ oxidation (DeAngelis and others 2010). These results highlight the fact that $\mathrm{O}_{2}$ can serve two functions in soils: accepting electrons and activating oxidative extracellular enzymes (Kristensen and others 1995). During anoxic periods, the former can be carried out by other terminal electron acceptors; the latter may be unimportant if the anoxic periods are relatively short in duration. That is, if there is sufficient labile $\mathrm{C}$ available during short anoxic periods or fluctuating redox conditions, then the lack of oxidative enzyme activity and associated breakdown of lignin molecules to simpler compounds would not limit overall C oxidation. In contrast, for soils or sediments that remain anoxic for months, the lack of $\mathrm{O}_{2}$ may result in slow decomposition and higher soil organic $\mathrm{C}$ content because there is relatively little breakdown of complex organic matter. In part, the significantly higher soil $\mathrm{C}$ in the cloud forest may be due to persistent anoxia. In Bisley, significant $\mathrm{C}$ oxidization could consistently occur as soils do periodically experience relatively oxic conditions.

The heterogeneous redox environment in these wet tropical forest soils presents challenges to predicting biogeochemistry, especially in the Bisley site. However, the ability to measure $\mathrm{O}_{2}$ continuously with sensors provides a major opportunity to improve our understanding of spatial and temporal biogeochemical dynamics. Although the mean $\mathrm{O}_{2}$ concentration often responded to precipitation events, the periodicity in the $\mathrm{O}_{2}$ and precipitation records exhibited the strongest coherence during rain-free periods of 5 or more days, allowing the soils time to dry down. The timing, not the amount, of rainfall appears to be a major driver of soil redox environment. Further, although the relationships between $\mathrm{O}_{2}$ and greenhouse gas concentrations in the soils were highly predictable, they were also strongly nonlinear for $\mathrm{N}_{2} \mathrm{O}$ and $\mathrm{CH}_{4}$. The fluctuating and often reducing soil environment driven by the timing of precipitation appears to be related to high concentrations of greenhouse gases in surface soils.

Redox has long been recognized as a major control on biogeochemical cycling. However, it has only rarely been quantified in upland soils. The results of this study highlight the spatial and temporal scale of variability in soil $\mathrm{O}_{2}$, and the strong linkages with the timing of precipitation events in these humid environments. The ability to measure $\mathrm{O}_{2}$ dynamics with continuously logging sensors should vastly improve our understanding of the spatial and temporal patterns of soil redox. These precipitation-driven redox fluctuations may play a crucial role in ecosystem structure and function for several reasons: (1) low and fluctuating redox dynamics appear to drive soil greenhouse gas concentrations in complex but predictable ways, (2) periods of higher and lower $\mathrm{O}_{2}$ availability may increase microbial diversity as many different metabolic strategies would be favored as redox conditions changed (Pett-Ridge and Firestone 2005; DeAngelis and others 2010), and (3) redox fluctuations may be associated with Fe reduction (Dubinsky and others 2010) and the release of labile P from geochemically associated pools, thus contributing to high NPP in P-poor soils (Chacon and others 2006; Liptzin and Silver 2009). Redox fluctuations are likely to play an important role in a wide range of upland ecosystems that experience perhumid conditions such as wet tropical forests, as well as those characterized by intense precipitation events and periods of soil saturation. 


\section{ACKNOWLEDGEMENTS}

This research was supported by NSF grants DEB 0543558 to W. Silver and DEB 0620910 to the Institute for Tropical Ecosystem Studies, University of Puerto Rico, and to the International Institute of Tropical Forestry USDA Forest Service, as part of the Long-Term Ecological Research Program in the Luquillo Experimental Forest. The U.S. Forest Service (Dept. of Agriculture) and the University of Puerto Rico gave additional support. Additional support was provided by Agricultural Experiment Station funds to W. Silver and from the International Institute of Tropical Forestry, USDA Forest Service. We would like to thank B. Quintero, T. Wood, and C. Torrens for help in the field.

\section{OPEN ACCESS}

This article is distributed under the terms of the Creative Commons Attribution Noncommercial License which permits any noncommercial use, distribution, and reproduction in any medium, provided the original author(s) and source are credited.

\section{REFERENCES}

Baldwin DS, Mitchell AM. 2000. The effects of drying and reflooding on the sediment and soil nutrient dynamics of lowland river-floodplain systems: a synthesis. Regul Rivers Res Manage 16:457-67.

Benzing DH. 1991. Aerial roots and their environments. In: Waisel Y, Eshel A, Eds. Plant roots: the hidden half. New York: Marcel Dekker, Inc.

Bollmann A, Conrad R. 1998. Influence of $\mathrm{O}_{2}$ availability on NO and $\mathrm{N}_{2} \mathrm{O}$ release by nitrification and denitrification. Global Change Biol 4:387-96.

Brown S, Lugo AE, Silander S, Liegel L. 1983. Research history and opportunities in the Luquillo Experimental Forest. General technical report SO-44. New Orleans: USDA Forest Service Southern Forest Experimental Station.

Cazelles B, Chavez M, Berteaux D, Ménard F, Vik JO, Jenouvrier S, Stenseth NC. 2008. Wavelet analysis of ecological time series. Oecologia 156:287-304.

Chacon N, Silver WL, Dubinsky EA, Cusack DF. 2006. Iron reduction and soil phosphorus solubilization in humid tropical forests soils: the roles of labile carbon pools and an electron shuttle compound. Biogeochemistry 78:67-84.

Cicerone RJ, Shetter JD. 1981. Sources of atmospheric methane: measurements in rice paddies and a discussion. J Geophys Res 86C:7203-9.

Cleveland CC, Townsend AR. 2006. Nitrogen and phosphorus additions cause substantial losses of soil carbon from a lowland tropical rain forest. Proc Natl Acad Sci USA 103:10316-21.

Davidson EA, Keller M, Erickson HE, Verchot LV, Veldkamp E. 2000. Testing a conceptual model of soil emissions of nitrous and nitric oxides. BioScience 50:667-80.

DeAngelis KM, Silver WL, Thompson AT, Firestone MK. 2010. Microbial communities acclimate to recurring changes in soil redox potential status. Environ Microbiol. doi:10.1111/j.14622920.2010.02286.x.

Dubinsky EA, Silver WL, Firestone MK. 2010. Tropical forest soil microbial communities couple iron and carbon biogeochemistry. Ecology 91:2604-12. doi:10.1890/09-1365.1.

Elliott ET, Heil JW, Kelly EF, Monger HC. 1999. Soil structural and other physical properties. In: Robertson GP, Coleman DC, Bledsoe CS, Sollins P, Eds. Standard soil methods for longterm ecological research. Oxford: Oxford University Press.

Fimmen RL, Richter DD Jr, Vasudevan D, Williams MA, West LT. 2008. Rhizogenic Fe-C redox cycling in deep upland soils: a hypothetical biogeochemical mechanism that drives crustal weathering. Biogeochemistry 87:127-41.

Firestone MK, Davidson EA. 1989. Microbiological basis of NO and $\mathrm{N}_{2} \mathrm{O}$ production and consumption in soil. In: Andreae MO, Schimel DS, Eds. Exchange of trace gases between terrestrial ecosystems and the atmosphere. New York: Wiley.

Frankenberg C, Bergamaschi P, Butz A, et al. 2008. Tropical methane emissions: a revised view from SCIAMACHY onboard ENVISAT. Geophys Res Lett 35:L15811. doi:10.1029/ 2008GL034300.

Gambrell RP, Patrick WH Jr. 1978. Chemical and microbiological properties of anaerobic soils and sediments. In: Hook DD, Crawford RMM, Eds. Plant life in anaerobic environments. Ann Arbor: Ann Arbor Science Publishers.

Gevantman LH. 2010. Solubility of selected gases in water. In: Haynes WM, Lide DR, Eds. CRC handbook of chemistry and physics 2010-2011. 91st edn. Boca Raton: CRC Press. p 80-3.

Grinsted A, Moore JC, Jevrejeva S. 2004. Application of the cross wavelet transform and wavelet coherence to geophysical time series. Nonlinear Process Geophys 11:561-6.

Iiyama I, Hasegawa S. 2009. In situ $\mathrm{CO}_{2}$ profiles with complementary monitoring of $\mathrm{O}_{2}$ in a drained peat layer. Soil Sci Plant Nutr 55:26-34.

Keeling RF, Severinghaus J. 2000. Atmospheric oxygen measurements and the carbon cycle. In: Wigley TML, Schimel DS, Eds. The carbon cycle, Vol. 6. Cambridge: Global Change Institute, Cambridge University Press.

Keller M, Kaplan WA, Wofsy SC. 1986. Emissions of $\mathrm{N}_{2} \mathrm{O}, \mathrm{CH}_{4}$ and $\mathrm{CO}_{2}$ from tropical forest soils. $\mathrm{J}$ Geophys Res 91:11791-802. doi:10.1029/JD091iD11p11791.

Kristensen E, Ahmed SI, Devol AH. 1995. Aerobic and anaerobic decomposition of organic matter in marine sediment: which is fastest? Limnol Oceanogr 40:1430-7.

Lau KM, Weng H. 1995. Climate signal detection using wavelet transform: how to make a time series sing. Bull Am Meteorol Soc 76:2391-402.

Liptzin D, Silver WL. 2009. Effects of carbon addition on iron and phosphorus in a tropical soil. Soil Biol Biochem 41:1696-702.

Lovley DR. 1991. Dissimilatory Fe(III) and Mn(IV) reduction. Microbiol Rev 55:259-87.

McGroddy M, Silver WL. 2000. Variations in belowground carbon storage and soils $\mathrm{CO}_{2}$ flux rates along a wet tropical climate gradient. Biotropica 32:614-24.

McSwiney CP, McDowell WH, Keller M. 2001. Distribution of nitrous oxide and regulators of its production across a tropical rainforest catena in the Luquillo Experimental Forest, Puerto Rico. Biogeochemistry 56:265-86.

Melillo JM, Steudler PA, Feigl BJ, Neill C, Garcia D, Piccolo MC, Cerri CC, Tian H. 2001. Nitrous oxide emissions from forests 
and pastures of various ages in the Brazilian Amazon. J Geophys Res 106(D24):34179-88.

Palus M. 2008. From nonlinearity to causality: statistical testing and inference of physical mechanisms underlying complex dynamics. Contemp Phys 48:307-48.

Peretyazhko T, Sposito G. 2005. Iron(III) reduction and phosphorous solubilization in humid tropical forest soils. Geochim Cosmochim Acta 69:3643-52.

Pett-Ridge J, Firestone MK. 2005. Redox fluctuation structures microbial community in a wet tropical soil. Appl Environ Microbiol 71:6998-7007.

Pett-Ridge J, Silver WL, Firestone M. 2006. Redox fluctuations frame microbial community impacts on $\mathrm{N}$-cycling rates in a humid tropical forest soil. Biogeochemistry 81:95-110.

Ponnamperuma FN. 1972. The chemistry of submerged soils. Adv Agron 26:29-96.

Scatena FN. 1989. An introduction to the physiography and history of the Bisley Experimental Watersheds in the Luquillo Mountains of Puerto Rico. General Technical Report SO-72. USDA. Forest Service Southern Forest Experimental Station, New Orleans.

Schuur EAG, Matson PA. 2001. Aboveground net primary productivity and nutrient cycling across a mesic to wet precipitation gradient in Hawaiian montane forest. Oecologia 128:431-42.

Seitzinger SP, Harrison JA, Bohlke JK, Bouwman AF, Lowarance R, Peterson BJ, Tobias C, Van Drecht G. 2006. Denitrification across landscapes and waterscapes: a synthesis. Ecol Appl 16:2064-90.

Sexstone AJ, Revsbech NP, Parkin TP, Tiedje JM. 1985. Direct measurement of oxygen profiles and denitrification rates in soil aggregates. Soil Sci Soc Am J 49:645-51.

Silver WL, Scatena FN, Johnson AH, Siccama TG, Sanchez MJ. 1994. Nutrient availability in a montane wet tropical forest in Puerto Rico: spatial patterns and methodological considerations. Plant Soil 164:129-45.

Silver WL, Lugo AE, Keller M. 1999. Soil oxygen availability and biogeochemistry along rainfall and topographic gradients in upland wet tropical forest soils. Biogeochemistry 44:301-28.

Silver WL, Herman DJ, Firestone MK. 2001. Dissimilatory nitrate reduction to ammonium in tropical forest soils. Ecology $82: 2410-16$
Silver WL, Thompson AW, Firestone MK, Reich A, Ewel JJ. 2005. Nitrogen cycling in tropical plantation forests: potential controls on nitrogen retention. Ecol Appl 15:1604-14.

Teh YA, Silver WL, Conrad ME. 2005. Oxygen effects on methane production and oxidation in humid tropical forest soils. Global Change Biology 11:1283-97.

Thompson A, Chadwick OA, Rancourt DG, Chorover J. 2006. Iron-oxide crystallinity increases during soil redox oscillations. Geochim Cosmochim Acta 70:1710-27.

Torrence C, Compo GP. 1998. A practical guide to wavelet analysis. Bull Am Meteorol Soc 79:61-78.

USDA NRCS. 2002. Soil survey of Caribbean National Forest and Luquillo Experimental Forest. Commonwealth of Puerto Rico. USDA, Natural Resources Conservation Service, Washington. p 181.

Vitousek PM, Matson PA. 1992. Tropical forests and trace gases: potential interactions between tropical biology and the atmospheric sciences. Biotropica 24:233-9.

Vitousek PM, Sanford RL Jr. 1986. Nutrient cycling in moist tropical forests. Annu Rev Ecol Syst 17:137-68.

Weaver PL. 1994. Bano de Oro Natural Area Luquillo Mountains, Puerto Rico. New Orleans: USDA Forest Service Southern Forest Experiment Station.

Weaver PL, Murphy PG. 1990. Forest structure and productivity in Puerto Rico's Luquillo Mountains. Biotropica 22:69-82.

Weaver PL, Medina E, Pool D, Dugger K, Gonzales-Liboy J, Cuevas E. 1986. Ecological observations in the dwarf cloud forest of the Luquillo Mountains of Puerto Rico. Biotropica 18:79-85.

Weiss R. 1970. The solubility of nitrogen, oxygen, and argon in water and seawater. Deep-Sea Res 17:721-35.

Weiss JV, Emerson D, Megonigal JP. 2005. Rhizosphere iron(iii) deposition and reduction in a Juncus effusus L.-dominated wetland. Soil Science Society of America Journal 69:1861-70.

Yates TT, Si BC, Farrell RE, Pennock DJ. 2007. Time, location, and scale dependence of soil nitrous oxide emissions, soil water, and temperature using wavelets, cross-wavelets, and wavelet coherency analysis. J Geophys Res 112:D09104. doi:10.1029/2006JD007662. 